\title{
Accessibility, ergonomics and functionality of museum environments: a systematic literature review considering integrated evaluation processes
}

\author{
Elisabeth Yang Nan Fu ${ }^{1}$. Sheila Walbe Ornstein ${ }^{1}$ (D)
}

Received: 18 June 2021 / Accepted: 14 October 2021/Published online: 11 November 2021

(c) The Author(s), under exclusive licence to Springer Nature Switzerland AG 2021

\begin{abstract}
This article presents a Systematic Literature Review (SLR) on Post-Occupancy Evaluation (POE) and Ergonomic Methodology of the Built Environment (EMBE) in museum environments. The main objective of this SLR was the collection and analysis of relevant literature and studies based on the following performance requirements and criteria: ergonomics, physical and cognitive accessibility of exhibitions, and the functionality of museum environments and their support areas, such as cafeteria, store, lockers/storage and box office, restrooms and their relations with the architecture of the building and the urban context they are inserted in. The results showed that there are many relevant and isolated studies on POE and EMBE applications, but do not encompass wide-ranging non-invasive methods focusing on the interfaces between architecture and design, especially in old buildings that house museums. The contribution of this article is to highlight an integrated POE - EMBE SLR of recent research approaches concerning design and architecture, approximating specific aspects of ergonomics and design and the performance of existing museum buildings in order to gain consistent diagnosis to support recommendations and decisions for future projects. In order to illustrate the SLR towards POE - EMBE integrated evaluative process as a potential methodological procedure, the case of the Museum of Image and Sound (MIS) located in São Paulo city, Brazil was selected.
\end{abstract}

Keywords Post-occupancy evaluation · Ergonomic methodology of the built environment $\cdot$ Museums $\cdot$ Exhibitions · Accessibility $\cdot$ Ergonomics

\section{Introduction}

The Post-Occupancy Evaluation (POE) and the Ergonomic Methodology of the Built Environment (EMBE) have been improved over the years. Similarly, buildings and how they are occupied have undergone transformations over the last decades. The objective of these methodologies is to understand whether the function prescribed for a given environment corresponds to the currently intended activity performed by this environment [1], enabling it to support adaptations according to the needs of users and to avoid

Elisabeth Yang Nan Fu

elisabeth.fu@usp.br

Sheila Walbe Ornstein

sheilawo@usp.br

1 Faculty of Architecture and Urbanism, University of São Paulo, São Paulo, SP, Brazil future failures in the design of similar buildings. The application of these methodologies in old buildings - several of them heritage ones - addresses issues of building performance, as in-depth ergonomic verification of the layouts of museum environments and their common facilities are not always carried out. This situation not only limits the enjoyment of museum environments but also the safety (especially those related to fire and accidents), the users' comfort, and the environmental requirements for preserving the exposed collections and collections storage in specific rooms. Thus, in order to promote a balance between these diverse performance criteria, it is important to study the interface between architectural and constructive elements and the usability of built environments, that is, ergonomics and cognitive and physical accessibility [2], in museums and exhibitions, through a SLR in relation to these interdisciplinary fields. This theoretical and methodological previous support qualifies the architectural programming of requirements. 
Table 1 Sample questionnaire form used in the MIS case study. Total numbers of respondents: 123 visitors

Form structure - Museum of Image and Sound (MIS)

\begin{tabular}{ll}
\hline Type of questions of each section of the form & Description \\
\hline Respondent profile (visitor) & $\begin{array}{c}\text { Multiple choice questions about gender, age, education level, number of visits, place of resi- } \\
\text { dence, transportation, and companion }\end{array}$ \\
Accessibility & $\begin{array}{c}\text { Questions with rating scale (very bad, bad, good, very good) about the urban context of the } \\
\text { museum, accessibility for older people, and access between floors of the building } \\
\text { Questions with rating (very bad, bad, good, very good) about the position of box office, } \\
\text { restaurant, restrooms, and rest areas }\end{array}$ \\
Support areas of the museum & $\begin{array}{l}\text { Questions with rating scale (very bad, bad, good, very good) about the visualization and } \\
\text { interactivity of museum objects, accessibility of exhibitions, and emergency exit signs and } \\
\text { directions }\end{array}$ \\
"When you think about MIS, what ideas or images come to mind?" (in order to support the \\
Open questions (address to text - open answers) \\
$\begin{array}{l}\text { constellation of attributes equation), "After the pandemic period, what do you think will } \\
\text { change in museum facilities?", and "Do you have any additional comments?" }\end{array}$
\end{tabular}

Source: the authors

The POE is a set of methods applied to evaluate the environmental performance of buildings in use [3], which allows quantitative results (related to technological issues) and qualitative results (associated with socio-psychological aspects) [4]. These results are based on measurements, observational descriptive and analytical surveys of the building, interviews with specialists and application of questionnaires with users who interact with the environment, such as museum visitors. Thus, the perception and satisfaction of users in relation to the built environment are part of the evaluation process and enable formulating diagnoses and recommendations [5]. The research was submitted and approved by the Ethics and Research Committee (CEP in Portuguese) at the School of Arts, Sciences and Humanities at the University of São Paulo (EACH USP in Portuguese) under the number CAAE 37102220.0.0000.5390 in October, 2020. CEP EACH USP approval of instruments applied to human beings is needed to carry out this type of research in Brazil.

Questionnaires were applied online due to the pandemic condition. They were organized on the Typeform platform and sent on November 19, to 28,786 visitors to the Museum listed on the Institution's mailing list. For the questionnaires to be considered valid, respondents had to meet the following prerequisites (at the top of the form): be of legal age (adults, aged over 18 years according to Brazilian law; have visited the museum in the last two years or until 2018 and agree to the Informed Consent Form). Due to the research term limitations, 181 respondents started filling out the questionnaire form and the filling of the questionnaires ended on December 17, 2020, comprising 123 valid completed questionnaires.

As an example of a questionnaire form, Table 1 shows the range of questions on the online form that asked about the Museum of Image and Sound (MIS) visitor's perceptions of the built environment and exhibitions. The pandemic situation limited the number of online responses to the questionnaire. On the other hand, reading the designs and interviews with experts and members of the museum's staff members contributed to the levels of confidence reached in the research.

In August 2020, the Museum had 89 employees and from these, seven staff members considered key people were selected to be interviewed based on semi-structured scripts. The interviewees had the following profiles: a collection supervisor, two educational coordinators, a programming coordinator, an audiovisual coordinator, a communication advisor and a maintenance, cleaning and purchasing coordinator. In addition to the seven employees, two architects were interviewed, one of them responsible for the largest renovation that has taken place in the building in recent years and the other an architect, a specialist in scenography and responsible for several exhibitions held at the Museum. All interviews also took place online from November 10, 2020 to December 16, 2020. The interviewees also agreed to the Informed Consent Form.

Some of the benefits for carrying out the POE include those in the short term, such as the identification and solution of facility problems, better management, the efficient use of the environment and maintenance costs. Those in the medium term consist of providing information for future adaptations of the building according to new needs. And, in the long term, those that provide feedback information for future projects of buildings with similar typologies, such as buildings that house museums.

Since 1960, the POE has been applied to different types of buildings and, today, it is increasingly related to the management of maintenance, performance and sustainability of buildings [6]. In Brazil, the application of POE started in the 1970s, with an important role in the life 
Fig. 1 POE in the project process for the continuous improvement of the built environment. Source: the authors

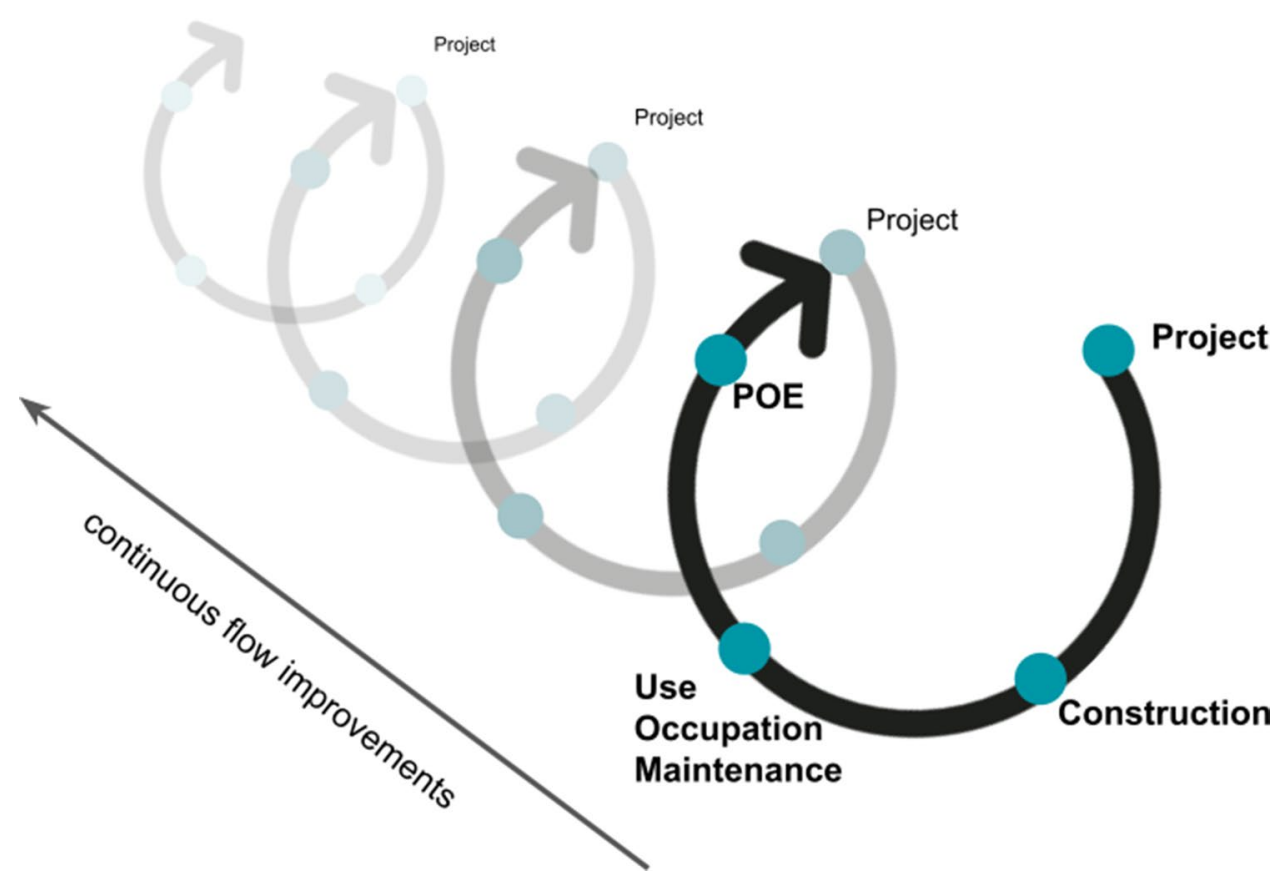

cycle of a building [7] as it contributes to improving the design process. POE includes all the phases as a project (here understood as design and other technical documents developed in the pre-construction phase), construction, use, operation and maintenance of the built environments. Nevertheless, the survey focuses on the evaluation stage of the post-occupied environment so as to complete the continuous improvement and feedback cycle (Fig. 1). Thus, its implementation requires an interdisciplinary approach due to socio-cultural changes and user expectations, in addition to the technological evolution of the building facilities. In this regard, highlighting the approximation of POE with other evaluation methods mainly in the area of design (from the perspective of ergonomics, for example), such as EMBE. [8].

On the other hand, in order to diagnose the man-activityenvironment system, the EMBE is focused on the functional building performance of the environments [9]. Which means an evaluation of the influence of the environment and objects on the task developed by the user.

As a result of ergonomic studies, the Human Factors and Ergonomics (HFE) of the built environment, the area of knowledge that gave rise to EMBE, considers aspects such as environment comfort (lighting, thermal, ventilation and acoustics), colors and textures, accessibility and anthropometric measures (layouts and dimensions), that enable creating recommendations through the application of EMBE in two phases: the evaluation of building performance (physical investigation) and the identification of the user's perception (cognitive investigation) in relation to a given environment [10].
As in the POE case, the EMBE can be represented as follows (Fig. 2):

The first phase of EMBE includes three stages: global analysis of the environment, which consists of identifying problems that require ergonomic intervention; identification of the environmental configuration, with a survey of all the physical data of the environment (layout, construction system, accessibility conditions, architectural designs); and evaluation of the environment in use regarding the performance of activities, when observations of the environment are made in order to identify its usability, that is, if the space allows developing a certain activity [9]. In this phase, an ergonomic diagnosis is produced and subsequently used for comparing the results of the second phase.

The second phase, in turn, consists of the stages: ergonomic diagnosis and ergonomic recommendations for the environment. The first stage uses instruments from environmental psychology, such as, the constellation of attributes (Fig. 3) to obtain the users' perception and ergonomic propositions for the environment. The second stage is composed of ergonomic recommendations for the environment according to the problems pointed out in the previous phase [10]. The latter, in addition to contributing improvements in the case study, can be considered for a future design proposal [12].

The constellation of attributes is a graphical representation that allows to discernibly analyze the associations of the users' spontaneous ideas of the environment by grouping the characteristics and calculating the psychological distance according to how often the attribute is mentioned. Thus, it helps to understand the users' psychological awareness or empathy towards the environment. The center of the 


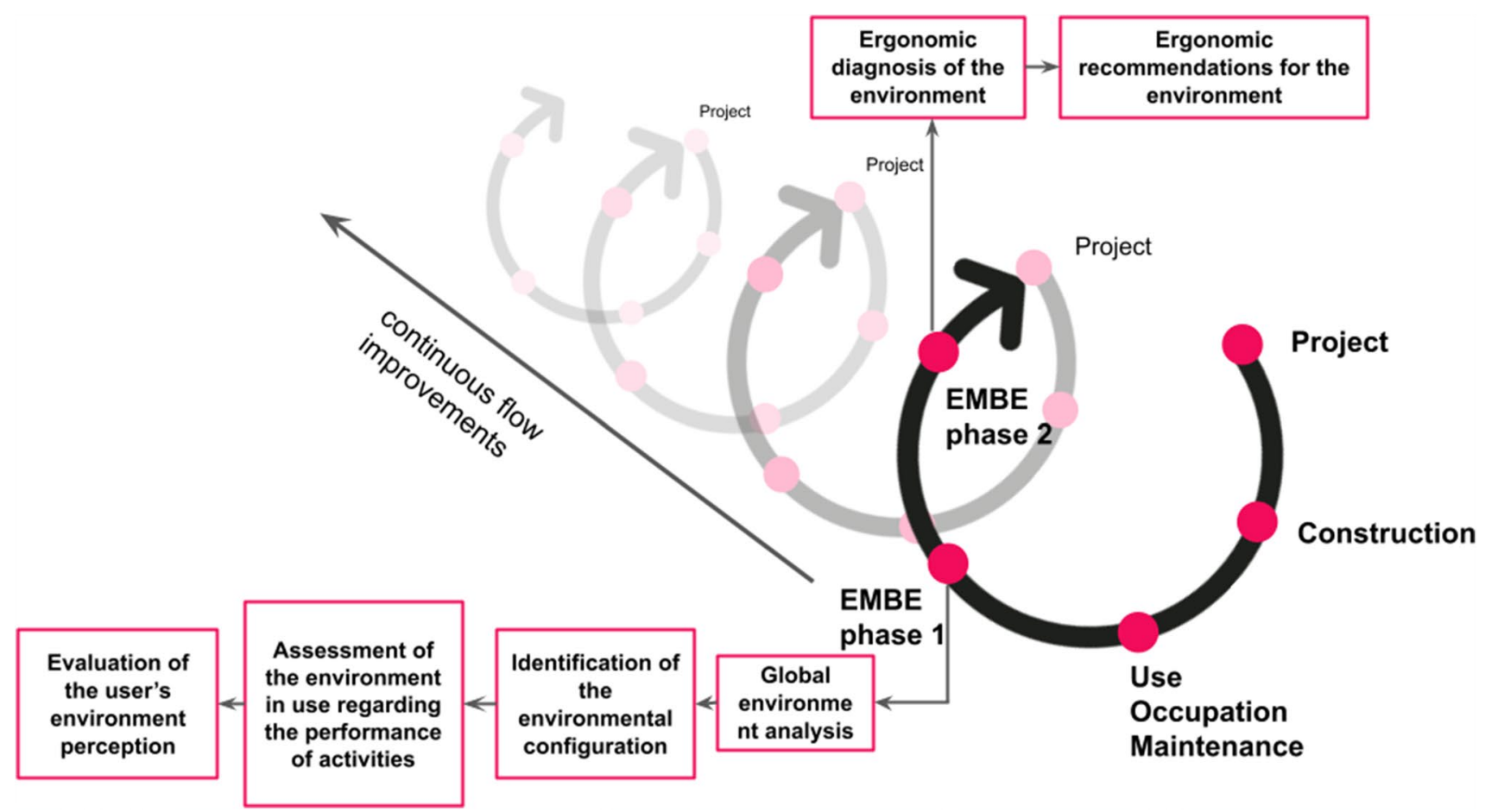

Fig. 2 EMBE in the design process for the continuous improvement of the built environment. Adapted from Sarmento and Villarouco (2020) [11]. Source: the authors

Fig. 3 Example of constellation of attributes of the real Museum of Image and Sound environment answering the question "When you think about MIS, what ideas or images come to mind?". Source: the authors through software available on the website http://www.fec. unicamp.br/ confterm/index. php?lang=en. Total number of respondents: 123 adults

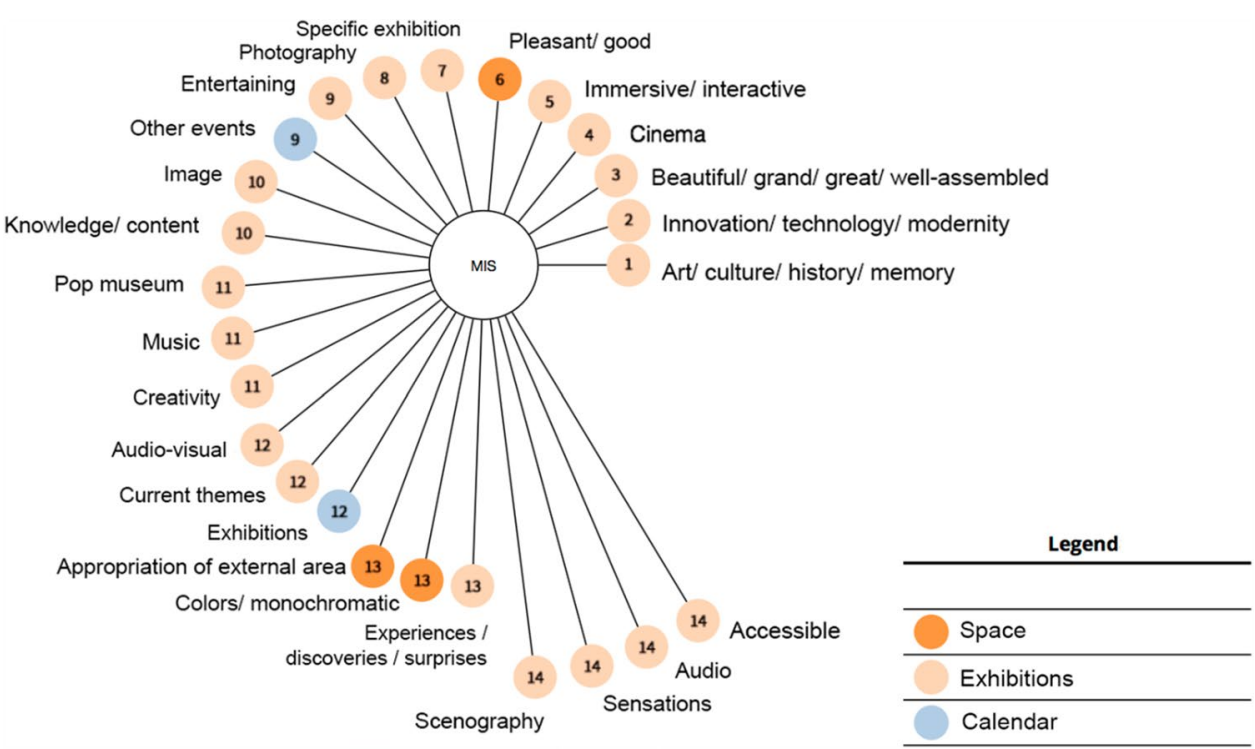

constellation is the study case, the elements furthest from the center demonstrate the users' lesser perception and ownership of the environment, while the closest elements are those that have a more direct and adaptable spatial relationship [13].

The following is an example of the constellation of attributes developed for the Museum of Image and Sound (MIS) case (see Table 1 and Fig. 2 above). For this purpose, the answers to the open-ended question of the online questionnaire applied to the adult visitors were used: "When you think about MIS, what ideas or images come to mind?" These answers were classified and numbered according to the frequencies in a decreasing order, that is, the ideas most quantitatively cited in the answers. The sample of people included in the constellation of attributes is the total number of questionnaire respondents (visitors). 
For the calculation of the psychological distance, the following equations (Eqs. 1 and 2 based in Paz, 2015 [13]) is used according to the software mentioned in Fig. 3:

$D=1 / \log P i$

D psychological distance of the attribute $(\mathrm{cm})$

$\mathrm{Pi}$ probability of association of attribute $i$ given by the formula (Eq.2):

$P i=100 *$ number of appearances of attribute $i$

It can be seen in the above example of the constellation of attributes that the theme of accessibility is the one that is the farthest from the central circle, that is, it was among the least commented by visitors in the open response to the questionnaire (see Table 1). However, from the evaluator's point of view, it is one of the most relevant themes and performance requirements to be considered when analyzing the design and improvements regarding the interfaces between architecture and exhibition layouts.

Both POE and EMBE start with an analysis of the configurations of the certain study case as MIS (spatial arrangements or layouts) and consider the users' perceptions in the evaluation process. However, many POE applications in case studies are more directed to Architecture and Urbanism (buildings and outdoor environments), while EMBE is for ergonomics in the environments, which is closer to the Design field. The approach of these methodologies associated with themes of ergonomics, accessibility and exhibitions, enable a more complete understanding of the relationship between the needs of users and the museum environments, with an emphasis on consolidation and mapping of diagnoses and recommendations for the case study (Fig. 4). POE and EMBE complement each other and are centered on the Built Environment versus Human Behavior relationships and not just on the environment or on the user [14].

Figure 4 shows another example of requirements mapping support in this article, such as accessibility, ergonomics and functionality of MIS environments.

\section{Systematic literature review: Procedures and results}

The bibliography selection process consisted of defining the keywords that, in turn, were inserted first in the online platform Integrated Search Portal (PBI) of the University of São Paulo, and later in Researchgate, Google Scholar, Scopus and ScienceDirect. In addition, the terms were also searched in Brazilian journals such as Anais do Museu Paulista (University of São Paulo - USP), Gestão \& Tecnologia de Projetos (USP), Cadernos do PROARQ (Federal University of Rio de Janeiro - UFRJ), Ambiente Construído (National Association of Built Environment Technology ANTAC), Projetar (Federal University of Rio Grande do Norte - UFRN), and international journals like Building and Environment and International Journal of Industrial Ergonomics.

After conducting online searches, the titles and abstracts of articles in the journals were verified and, if relevant to the research, these publications were analyzed in depth. If new keywords were discovered, it would undergo the same process, allowing to update the review with the addition of new bibliographies.

The following flowchart (Fig. 5) represents the keywords and developments of the main expressions. These words direct the selection of bibliographies that more closely respond to the objectives of the POE and EMBE research in the MIS case study, such as "accessibility in museums" or "Post-Occupancy Evaluation in museums," or "Ergonomic Methodology of the Built Environment" since many of the terms present broad search results.

In the bibliographic verification stage by titles and abstracts, selection was made following exclusion and inclusion criteria, as shown in Table 2 below.

The works were first collected on the USP Integrated Search Portal (PBI), following the time selection criteria, published in the period 2010-2020, in English and Portuguese and covering content related to the built environment, ergonomics, museum and museum exhibitions, excluding those that do not contemplate these aspects and those that are not available for online reading.

After this initial selection, the search was carried out in already mentioned periodicals, journals and other databases and theses, using the same filtering criteria, but with a time selection extended to 20 years (2000-2020).

To further expand the search for works relevant to the research, the sites used were Brazilian Institute of Museums $\left(\right.$ IBRAM $\left.^{1}\right)$, International Council of Museums $\left(\mathrm{ICOM}^{2}\right)$ and State System of Museums of São Paulo (SISEM ${ }^{3}$ ). The criteria for selecting these new bibliographies were the same as those mentioned in Table 2, except for the time frame, which to include more studies, was increased for the period 2000-2020.

After the final selection of works, a map was created to indicate the countries of origin of the references found and a flowchart separating the bibliographies by subject.

\footnotetext{
${ }^{1}$ IBRAM e-mail address: https://www.museus.gov.br/categoria/publi cacoes/revistas/

${ }^{2}$ ICOM e-mail address: https://icom.museum/en/resources/stand ards-guidelines/standards/

${ }^{3}$ SISEM e-mail address: https://www.sisemsp.org.br
} 


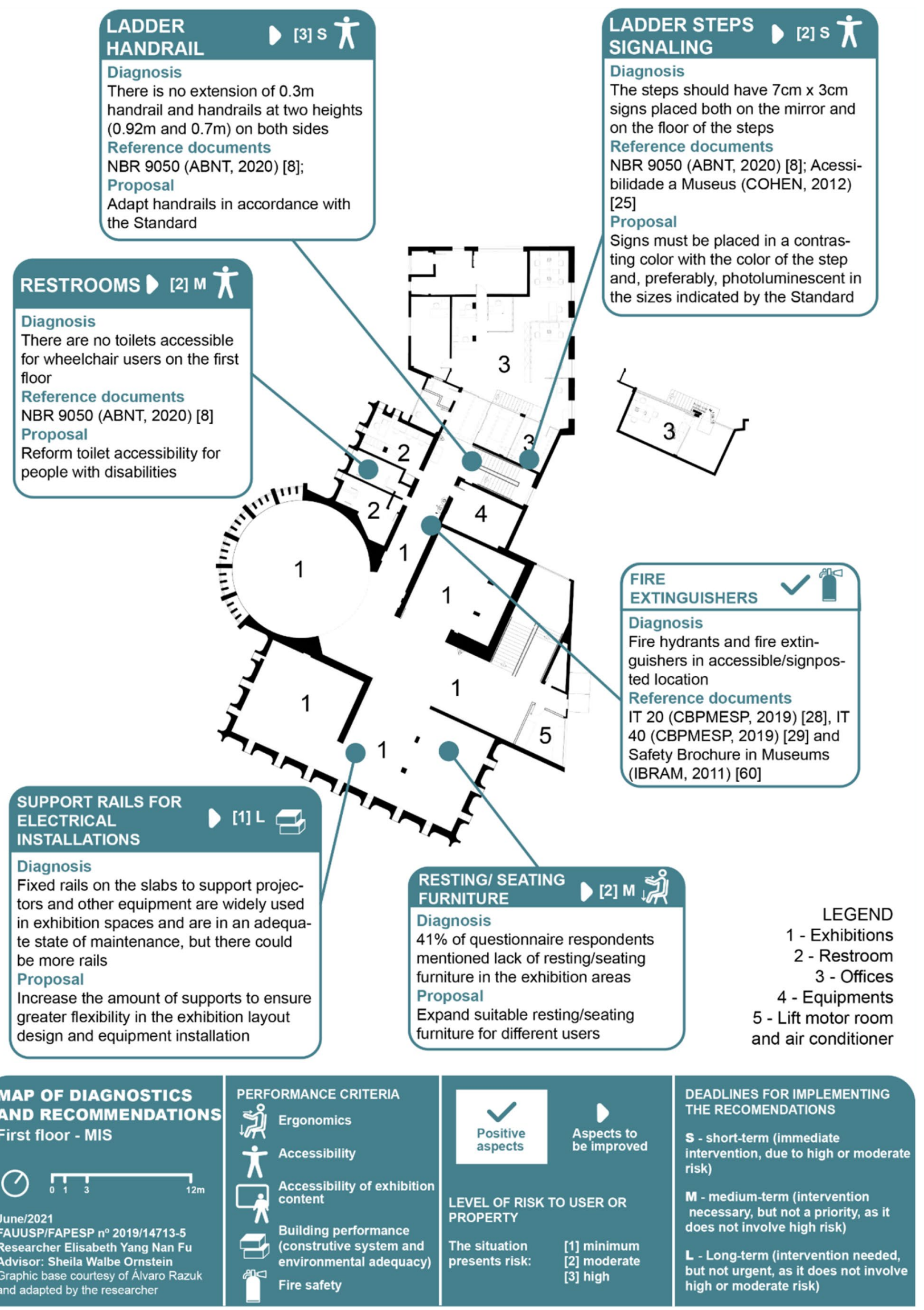


4Fig. 4 Example of a diagnostics and recommendations map on the first floor of the MIS. Graphic database adapted from Ono, et al. (2018) [5] on a design made available by the architect Alvaro Razuk and adapted by the authors

Works on MIS were also selected, the research case study, in addition to Brazilian standards for building performance, accessibility and ergonomics, technical instructions for fire safety, municipal legislation for buildings and others, and national and international museum guideline regulations from the Brazilian Institute of Museums and documents from ICOM.

Figure 6, below, shows the 64 articles selected by subject and according to search platforms (without the inclusion of standards):

There were several POE bibliographies in the first PBIbased searches. As for references to accessibility and EMBE, many were obtained from journals, since the articles in events annals such as the National Meeting of Ergonomics of the Built Environment - ENEAC [15, 16] and the National Meeting of Technology in the Built Environment - ENTAC [1] are predominantly directed at these themes. It is also observed that there were no studies on EMBE, a methodology created in Brazil, in ScienceDirect, where there are mostly international works.

The platform Integrated Search Portal (PBI) also featured articles published in journals, which were counted in the "PBI" column of Fig. 7, that is, even though they were articles in journals, they were not inserted in the column count "Journals", obeying a search hierarchy between platforms, starting first with PBI research, then ScienceDirect, Google Scholar and, finally, journals.

Thus, the number of papers selected by subject is summarized in Table 3 below:

In other words, SLR can be demonstrated with the main documents consulted in the flowchart (Fig. 7), below.

The origin of the 64 selected bibliographies were identified. As the research is based in Brazil, most of the bibliographies are Brazilian. Regarding international references, there is a greater number of references in the United Kingdom and North America, and others in Europe and Asia.

As for the bibliographies related to POE and EMBE, the studies sought were those that substantiate and explain the procedures that must be followed. In addition to these articles, works that demonstrate methods applied in other museums or public buildings were included. These buildings shall be of typologies that are closer to museums (learning facilities) such as schools (educational ones), since they enable comparing the results and the challenges faced during the application of the evaluation methods of the built environments.

In the case of POE, Ono, et al. (2018) [5], Rheingantz, et al. (2009) [17], and Voordt (2012) [6] are important references for understanding the methodology in terms of its historical, technical and practical aspects. In addition to these, publications such as Li, et al. (2018) [7] published in the journal Building and Environment and articles by Ornstein in the journals PARC - Pesquisa em Arquitetura e Construção, State University of Campinas (UNICAMP - 2016) [18], and Projetar - Federal University of Rio Grande do Norte (UFRN - 2017) [8], are relevant to incorporate current and future perspectives [19], benefits, limits and objectives on the practice of POE in recent discussions [4].

Regarding the journals that consider articles on these methods, there are POE references applied in other museums such as in the journals Cadernos do PROARQ - Faculty of Architecture and Urbanism of the Federal University of Rio de Janeiro (FAU UFRJ) [20], Anais do Museu Paulista [21] and Projetar - UFRN [22], the case of applying POE in preschools that consider the inclusion of children with hearing, visual and physical disabilities in the POE process [23], and international references such as the case of applying POE in the Department of Architecture and Engineering at Salahaddin University, Iraq [24], and the case of applying POE in campus buildings of Chongqing University of Science and Technology, China [25].

In the case of EMBE, the theoretical basis consisted of bibliographies on the method along with those that contain principles of ergonomics - user and activity [10] in relation to the built environment [26] such as Sarmento and Villarouco (2020) [12], Sarmento, Villarouco, and Gomes (2020) [27] published in the journal Ambiente Construído ANTAC, Attaianese and Duca (2012) [28] published in the journal Theoretical Issues in Ergonomics Science and Costa and Villarouco (2014) [9].

For studies that applied the EMBE in a case study, the ones selected were those whose functional aspects are in some way close to the utilization of the museum, a space for collective use, often a public space. These are the cases of Vasconcelos, Villarouco and Soares (2009) [29], where EMBE was applied in a university library, Castro and Batista (2014) [1] and Cruz (2006) [2]. The last two mentioned used the principles of POE, in addition to ergonomics and were carried out in environments of schools of Architecture and Design [1, 2].

Other works can be mentioned, such as Araújo, et al. (2020) [30], Villarouco, et al. (2020) [31], Felix Neto, et al. (2020) [32] and Paz (2015) [13], which used the constellation of attributes as a tool of environmental psychology (a tool widely used in EMBE evaluations). The latter was an exception because it is not a university environment, but a hospital environment.

Regarding accessibility, in addition to the standards inserted in the SLR process, which will be described later, Heylighen et al. [33] and Steinfeld; Maisel [34] comprehensively addresses questions about universal design: principles and barriers. Also, the Cadernos Museológicos of IBRAM are indispensable, such as Volume 2 [35], where 
Fig. 5 Flowchart of the main terms - in Portuguese and in English - to support the research. Source: the authors

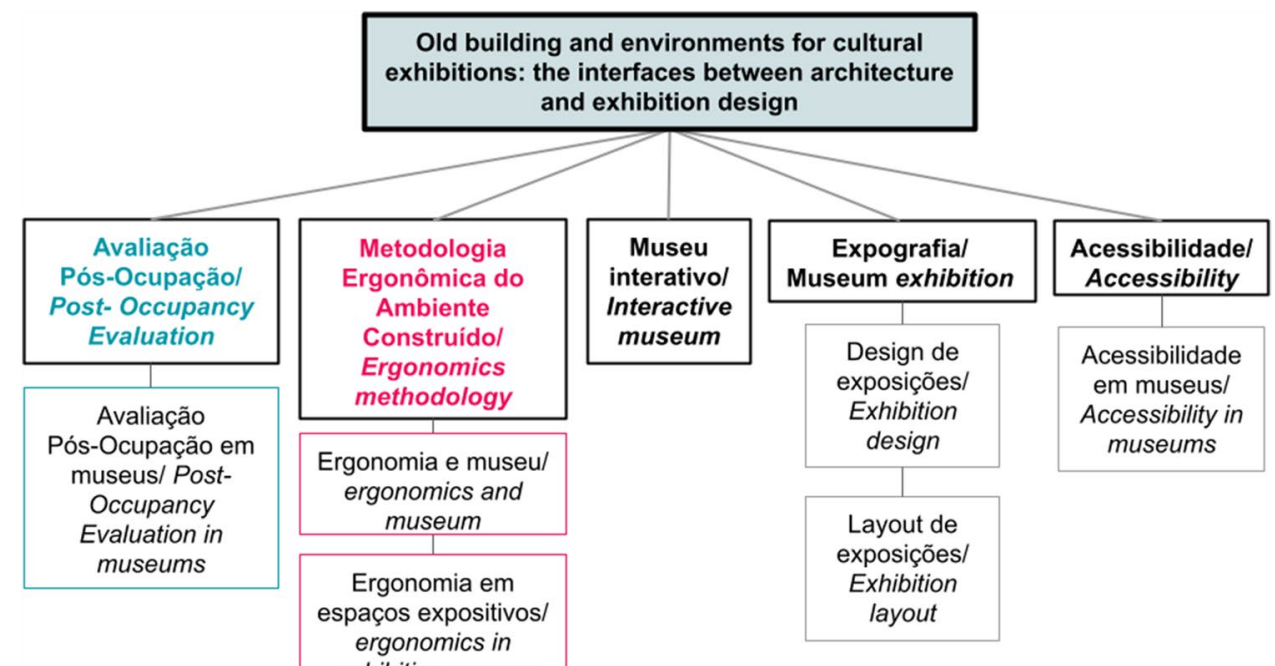

Table 2 SLR filtering: inclusion and exclusion criteria for bibliographies

\begin{tabular}{ll}
\hline SLR Filtering & \\
\hline Criteria & Content \\
\hline Inclusion & - Articles published between 2010 and 2020; \\
& - Language: English or Portuguese; \\
& - Articles focusing on POEs and EMBEs applied in museums, public buildings or schools; \\
& - Articles that provide theoretical basis on POE, EMBE, ergonomics, accessibility, exhibition \\
& designs and interactive museums; \\
& - Articles with intersections between the themes of the previous item. \\
& - Articles unavailable online or paid; \\
Exclusion & - Articles that do not address aspects of the built environment or museums or exhibition designs;
\end{tabular}

Source: the authors

Total works selected by search platform

PBI Science Direct $\square$ Google Scholar Jounals

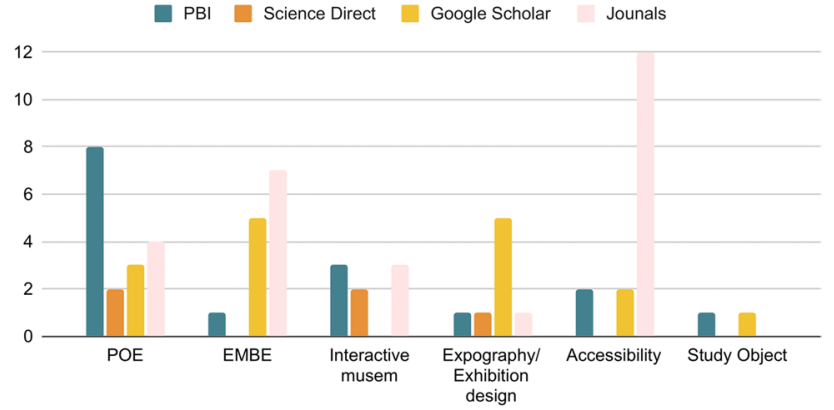

Fig. 6 Total selected articles (absolute numbers) by search platform between 2000 and 2020. Source: the authors

all of museum accessibility aspects are addressed in detail, from basic concepts to aspects of the building, of the object (expography), safety (signaling) and examples from Brazilian and international museums. In this regard, Sarraf [36] discusses the role of museums with the inclusion of people with hearing, physical, visual [37] and cognitive [38] disabilities to access culture. It also presents practical and theoretical support that must be incorporated into museums so that everyone has access to information, art and cultural heritage. Furthermore, other articles show how architecture can contribute to it [39] through universal design [40], ergonomics [41] and usability study [42], eliminating physical barriers [43] and communication for the numerous users such as the elderly, people with reduced mobility, visual impairment [44] and hearing impairment [45].

This research also analyzes the museum's support areas (common facilities), references and guidelines for restrooms which are part of the themes of accessibility and user-centered ergonomics [46]. Regarding accessibility in urban spaces, works published in the journal Projetar such as Silveira (2017) [11], and in the articles of the proceedings National Meeting of Ergonomics in the Built Environment ENEAC $[15,16]$ highlight the needs of people with reduced mobility and visual impairment in order to subsequently support the application of POE and EMBE instruments in the urban surroundings of the case study. 
The topic of museum safety was addressed in Cadernos Museológicos Volume 1 [47], which presents guidelines for the elaboration of safety plans for the preservation of collections and human life against theft, fires and other disasters. These measures covered aspects of the building's treatment, maintenance and operational control (as regards safety personnel).

In Cadernos Museológicos Volume 3 [48], the approach took place in the exhibitions. It highlighted the chapters on fire safety and emergency plans and on accessibility and the educational dimensions of expography, considering the increased concern with visitors, which leads to new ways of exhibiting the collection, as well as museum communication.

In Exhibition Design and Aesthetic Experience at the Contemporary Museum [49], basic concepts are presented on exhibition design and experiential design in relation to communication and the role of the designer. In this regard, Primo [50] emphasizes the expository role regarding the preservation of memory in society, in order to better understand the present time. Therefore, the museum object must communicate using technological resources (lighting, interactivity, sound effects) not only to highlight a collection, but to create an immersion in the context of the entire exhibition, which involves setting up scenography, using digital resources and replicas of the original collection (manageable objects) so they can interact with the public. However, Ennes [51], points out that these elements should not take the focus away from the main subject of an expographic discourse, and also discusses the effects of itinerant and permanent exhibitions in the building, as well as analyzing the different languages used in Brazilian museums to comply with the communicational function of the museum. "An exhibition is an interaction in a space between people, form and content, objects and means for emotional experience and knowledge." (ENNES, 2008, p.102) [51].

The term Human-Exhibition Interaction (HEI) has been used in the practice of exhibition design projects. It involves aspects of interactive "man-exhibition" communication in the spheres of the designer, the client and the experience, and visitor behavior [52]. In this perspective, Mustafa; Taha [53] analyzed the different flows of visitors and the length of stay at each museum object according to each museum exhibition layout in Qatar, while Medeiros et al. [54], in an article published in the journal Estudos em Design, analyzed these aspects in a Brazilian case, also considering elements of lighting and sound. Chelini; Lopes [55], in turn, pointed out important topics for evaluating an exhibition, taking into account different levels of interaction and ways of displaying accessibility aspects.

As for the conservation and management of expography, Pavlogeorgatos [41] presented several parameters of environmental conditions for these purposes. Entities like ICOM-CC [56] and UNESCO [57] also have guidelines that should be taken into account.
As for the case study, characteristics of interactive museums were also investigated. Machado [58] presented basic concepts of interactive expographic design; Lupo [59] discussed the limits of interaction, questioning its relationship with the visitors' learning and their interest in interactive objects within the museum space. Those spaces, provided by architecture, impose flows and infrastructure for a feasible exhibition. In this regard, Ahmad et al. [60] and Ahmad [61] compare the effects of static and interactive objects on the visitors' learning experience in museum exhibitions and define the best ways to display the best engagement, communicative potential and understanding of museum content to the different profiles of "students." Rahimi [62], in turn, explored the public's relationship with the activity and context of immersive environments from the standpoint of creating an interactive experience or "experience design."

Regarding the specific review of standards in order to formulate the checklists that support walkthroughs, which is one of the main research scopes that originated this SLR, the selection and consultation of standards were also very relevant to evaluate the physical environments.

ICOM provides several documents and guidelines with recommendations for good museum practices. Some of them highlight recommendations for documenting objects according to their categories [63], collection and expography conservation standards [56], planning and evaluation of educational and cultural programs in museums [64], and the Code of Ethics of the ICOM for Museums, which focuses on preservation and learning aspects, in addition to the social function of museums and professional practices [65].

Other international recommendations that must be taken into account are those of the United Nations Educational, Scientific and Cultural Organization (UNESCO), which defines guidelines for the promotion and conservation of museums and their role in society to its member countries [57].

On the other hand, the case study is subject to Brazilian Standards (ABNT - Brazilian Association of Technical Standards) and, therefore, the themes of the standards selected were those that are related to buildings, accessibility, ergonomics and safety.

As for building performance, NBR 15575 [66] and NBR ISO 41001 [67] are important because they are requirements for buildings in terms of comfort, accessibility, structural and fire safety, construction and preventive and corrective maintenance, considering costs and process optimization in the scenario of sustainable measures (facilities management). Thus, for the users' best museum experience, there are standards related to the acoustic and lighting comfort of indoor environments such as NBR 10152 [68], with parameters to perform measurements according to the use of each environment. Another safety standard is NBR 10898 [69], regarding emergency lighting system.

NBR 9050 [70] standards are relevant for the accessibility measures, with mobility and perception parameters of 


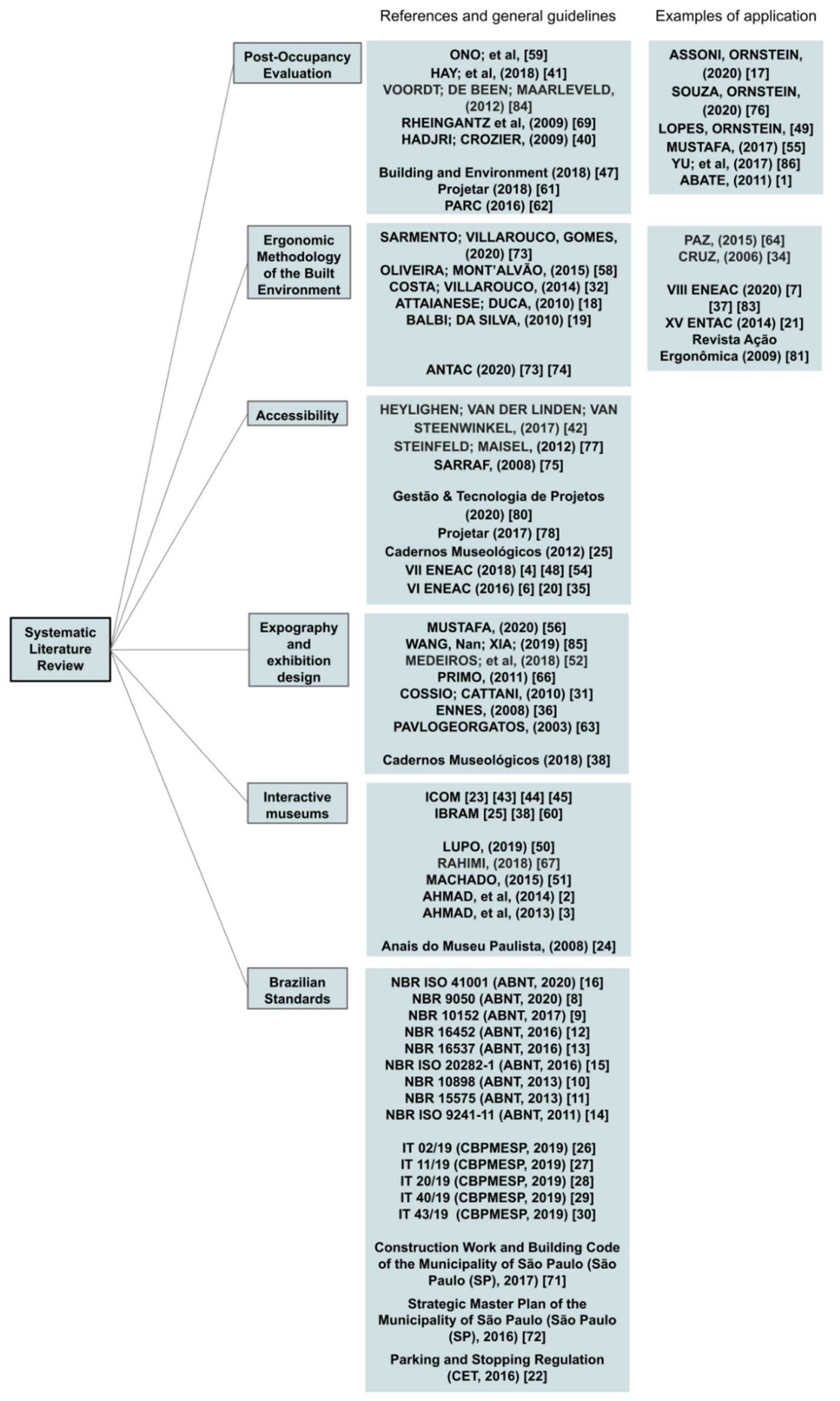


Fig. 7 Bibliographies divided by subject. Source: the authors

the environment in order to provide autonomy to the individuals in buildings, environments and urban areas. Furthermore, NBR 16452 [71] provides production guidelines for audio description of audiovisual products and services; and NBR 16537 [72] for tactile floor installation. In addition to these, the Parking and Stopping Regulation, Volume 10 "has design criteria for signaling stretches of public roads, intended for the exclusive parking of a vehicle or one that transports people with physical or visual disabilities" (CET, 2016, p.1) [73].

Regarding ergonomics, NBR ISO 20282-1 [74] is essential for analyzing everyday objects in terms of usability, while NBR ISO 9241-11 [75] addresses this usability in the context of visual interaction with devices. In addition, NR 17 [76] has ergonomic guidelines applicable to the psychophysiological characteristics of those who are going to perform work related activities, in order to guarantee maximum comfort and safety. In this regard, the museum facility is evaluated with respect to user parameters.

The technical instructions (TIs) of the Fire Department of the Military Police of the State of São Paulo (CBPMESP) were also considered to support the evaluation in relation to fire safety. Standards such as TI 02 [77] regarding basic concepts, TI 11 [78] about requirements for emergency exits, TI 20 [79] about emergency signs, TI 40 [80] about fire safety in buildings which hold collections, such as museums and historic buildings, and TI 43 [81] related to the adaptation of existing buildings according to the necessary safety conditions, are central to survey parameters regarding fire safety.

Another document to be considered is the Building and Work Code of the Municipality of São Paulo (2017), which has regulations for the construction, occupation, renovation and expansion of buildings, including listed heritage properties [82], in accordance with the urban zoning guidelines of the Strategic Master Plan of the Municipality of São Paulo for the Neighborhoods called "Jardins", the location of MISSP [83].

\section{Discussion}

The objective of this SLR was to assemble relevant studies within the selected themes. Most of the studies address architecture and its users in terms of ergonomics, within the scope of POE or EMBE methodology, however, further studies are needed regarding the dynamics between museums in old buildings and interactive exhibitions (regarding MIS), although there are some museum documents and brochures with recommendations and guidelines [48, 64], and some studies [20, 22] that bring these themes together. It is also significant that there are case studies that validate POE and EMBE applications in an integrated manner, especially in old buildings, in addition to educational buildings such as schools and libraries [1, 2, 14, 24, 25, 29-32], in order to compare, analyze and share solutions and problems encountered specifically in museums (benchmarking) [20-22], also a basis for future museum projects $[5,6]$.

Moreover, most of the technical literature, norms and codes deal with the conservation and use of old buildings in a very isolated way, subject by subject and except for some proposals like [84], it will usually depend on each professional and research to show, according to their own personal practice, how to diagnose and propose solutions for each constructive, comfort, safety, accessibility, ergonomics and functional findings. The SLR revealed many interesting and useful evaluation processes, but they only focus on a specific theme or constructive or functional elements and not on the full environment itself in an integrative way. As a result, technical problems are partially resolved or may even increase risks and reduce the useful life of old buildings.

A strategic and integrative approach that brings together the best of POE and EMBE evaluation processes could help in the conservation of old buildings that house museums and different users, mainly in developing countries.

\section{Conclusions}

It can also be observed, based on the SLR carried out, that POE and EMBE present very similar methodological procedures [14]. POE can be considered as a broad strategic approach that encompasses practically all performance criteria for urban, public spaces and built environments, while EMBE has a more specific and targeted approach to ergonomics and accessibility. In spite of the need to expand studies on the integration of POE and EMBE, in general, SLR indicates that for the case of museum environments, the combined form of performance evaluation in use of the two procedures may help with consistent information for the adaptation of museum environments, from the layout of
Table 3 Total works selected by theme

\begin{tabular}{lllllll}
\hline \multicolumn{2}{l}{ Selected works by theme } \\
\hline POE & EMBE & Interactive Museum & Expography/Exhibition Design & Accessibility & MIS-SP & Total \\
\hline 17 & 13 & 8 & 8 & 16 & 2 & 64 \\
\hline
\end{tabular}

Source: the authors 
the exhibitions, to also including the building and the urban context in which a given Museum is inserted.

Thus, with the contributions of these methods, the goal of this article is to identify museum aspects that can be improved, especially in the case of old buildings and their urban surroundings. Based on the SLR, the integrative use of both POE and EMBE could help to find solutions that meet contemporary demands, with regard to museum environments and their users, but even POE and EMBE applied as integrative methodological procedures, as contemporary non-invasive tools, are far from supporting all performance needs of old buildings in order to meet all technical and functional requirements in relation to exhibition layouts and building interfaces and also building and outdoor / urban surroundings area interfaces.

The systematic literature and normative review and the application in this research of the POE and EMBE integrated methodological procedures demonstrated the complexity of maintaining an old building, at its origin a residence with rooms limited by its dimensions and transformed into a contemporary interactive museum. An interactive museum requires apparatus in terms of electrical installations, efficient lighting supports fixed on grids, exciting and safety routes and equipments with its design based on ergonomic, accessibility and functionality assumptions for visitors with varied profiles, including the elderly and people with disabilities.

Many old buildings that house museums are part of the city's history and memory, so the challenge to maintain the performance criteria requirements on non-invasive and cost-effective visual measurements and instruments is not unique. The challenge regarding low-run environmental management is even greater when performance requirements refer to important old buildings located in poor or developing countries in the southern hemisphere. In order to achieve this goal, additional methodological and integrative models that address a range of different diagnostics and recommendations in a flexible way but based on a strong normative background still need to be tested in future research.

Supplementary Information The online version contains supplementary material available at https://doi.org/10.1007/s44150-021-00013-w.

Acknowledgments The author Elisabeth Yang Nan Fu thanks the São Paulo Research Foundation (Fapesp - process 2019/14713-5) for the Scientific Initiation scholarship received, and the author Sheila Walbe Ornstein thanks the National Council for Scientific and Technological Development (CNPq process 304131/2020-2) for the productivity grant received.

Funding This research was supported by the São Paulo Research Foundation (FAPESP) under process No. 2019/14713-5 and by the National Council for Scientific and Technological Development (CNPq) under process No. 304131/2020-2.

\section{Declarations}

Conflict of interest The authors have no conflicts of interest to declare that are relevant to the content of this article.

\section{References}

1. Castro IS, Batista MO (2014) Análise do Ambiente Construído Baseado na Avaliação Pós-Ocupação e na Análise Ergonômica do Trabalho. XV Encontro Nacional de Tecnologia do Ambiente Construído, ENTAC-2014. Maceió, AL. Available at: http://www. infohab.org.br/entac2014/artigos/paper_462.pdf. Accessed 11 Oct 2020

2. da Cruz RRS (2006) Avaliação pós-ocupação e apreciação ergonômica do ambiente construído: um estudo de caso (Master's thesis, Universidade Federal de Pernambuco). Available at: https://repositorio.ufpe.br/handle/123456789/5824. Accessed 17 Sept 2020

3. Council, F. F., \& National Research Council (2002) Learning from our buildings: A state-of-the-practice summary of post-occupancy evaluation (Vol. 145). National Academies Press Available at: https://www.nap.edu/read/10288/chapter/1. Accessed 19 Jun 2019

4. Hadjri K, Crozier C (2009) Post-occupancy evaluation: purpose, benefits and barriers. Facilities. Available at: https://www.resea rchgate.net/publication/235263738_Post-occupancy_evaluation_ Purpose_benefits_and_barriers. Accessed 27 Sept 2020

5. Ono R, Ornstein SW, Villa SB, França AJGL (2018) Avaliação Pós-Ocupação: na arquitetura, no urbanismo e no design. Oficina de Textos

6. Voordt TJ van der, de Been I, Maarleveld M (2012) Post-occupancy evaluation of facilities change. Facilities change management 137. Available at: https://www.researchgate.net/publication/ 235916957_Post-Occupancy_Evaluation_of_Facilities_Change. Accessed 23 Sept 2020

7. Li P, Froese TM, Brager G (2018) Post-occupancy evaluation: state-of-the-art analysis and state-of-the-practice review. Build Environ 133:187-202 Available at: https://www.sciencedirect. com/science/article/pii/S0360132318300957. Accessed 17 Sept 2020

8. Ornstein SW (2017) Avaliação Pós-Ocupação (APO) no Brasil, 30 anos: o que há de novo?. Revista Projetar-Projeto e Percepção do Ambiente 2(2): 7-12. Available at: https://periodicos.ufrn.br/ revprojetar/article/view/16580. Accessed 17 Sept 2020

9. Costa A, Villarouco V (2014) Que metodologia usar? Um estudo comparativo de três avaliações ergonômicas em ambientes construídos. MONT'ALVÃO, C.; VILLAROUCO, V. Um novo olhar para o projeto: a ergonomia no ambiente construído. Recife: Editora UFPE, 247

10. de Oliveira GR, Mont'Alvão CR (2015) Metodologias utilizadas nos estudos de ergonomia do ambiente construído e uma proposta de modelagem para projetos de design de interiores. Estudos em Des 23(3):150-165 Available at: https://eed.emnuvens.com.br/ design/article/view/276. Accessed 23 Sept. 2020

11. Silveira CS, Dischinger M (2017) Espaços urbanos inclusivos: a utilização da áudio-descrição e da sinalização tátil para incluir pessoas com deficiência visual. Revista Projetar-Projeto e Percepção do Ambiente 2(2): 122-133. Available at: https://periodicos. ufrn.br/revprojetar/article/view/16584. Accessed 27 sept 2020

12. Sarmento TS, Villarouco V (2020) Projetar o ambiente construído com base em princípios ergonômicos. Ambiente Construído 20(3): 121-140. Available at: http://www.scielo.br/scielo.php? script $=$ sci_arttext $\&$ pid $=$ S1678-86212020000300121\&lng $=$ pt $\&$ nrm=iso. Accessed 16 Sept 2020 
13. Paz CMD (2015) Ergonomia em ambientes hospitalares: diretrizes para a concepção de cozinhas e lavanderias baseado em um estudo de caso (Master's thesis, Universidade Federal de Pernambuco). Available at: https://repositorio.ufpe.br/bitstream/123456789/ 15497/1/DISSERTAÇÃO\%20Carla\%20Maria\%20da\%20Paz.pdf. Accessed 9 Nov 2020

14. Fu EYN (2021) Edifício antigo e ambientes para exposições culturais: as interfaces entre arquitetura e design de exposições (Relatório Final de Iniciação Científica, Fundação de Amparo à Pesquisa do Estado de São Paulo - FAPESP n ${ }^{\circ}$ 2019/14713-5)

15. Almeida EAM, de Nogueira DL, Costa ADL (2018). O papel da interdisciplinaridade na avaliação da acessibilidade em ambiente urbano público. In: VII Encontro Nacional de Ergonomia do Ambiente Construído / VIII Seminário Brasileiro de Acessibilidade Integral, v. 4, n. 2 p. 465-476. In: São Paulo: Blücher, 2018. Available at: http://pdf.blucher.com.br.s3-sa-east-1.amazo naws.com/designproceedings/eneac2018/036.pdf. Accessed 24 Sept 2020

16. Morano RP, Santiago ZMP (2018) Percursos Urbanos: Uma análise da acessibilidade sob a perspectiva das pessoas com deficiência visual. VII Encontro Nacional de Ergonomia do Ambiente Construído / VIII Seminário Brasileiro de Acessibilidade Integral 4(2): 261-272. São Paulo: Blucher. Available at: http://pdf.bluch er.com.br.s3-sa-east-1.amazonaws.com/designproceedings/eneac 2018/017.pdf. Access 24 Sept 2020

17. Rheingantz PA, Azevedo GA, Brasileiro A, Alcantara DD, Queiroz M (2009) Observando a qualidade do lugar: procedimentos para a avaliação pós-ocupação. Rio de Janeiro: Universidade Federal do Rio de Janeiro, Faculdade de Arquitetura e Urbanismo, Pós-Graduação em Arquitetura. Available at: https://www.acade mia.edu/39061401/Paulo_Afonso_Rheingantz_Observando_a_ qualidade_do_lugar_Procedimentos_para_a_avaliação_pós_ ocupação. Accessed 14 Sept 2020

18. Ornstein SW (2016) Com os usuários em mente: um desafio para a boa prática arquitetônica?. PARC Pesquisa em Arquitetura e Construção 7(3): 189-197. Available at: https://periodicos.sbu.unica mp.br/ojs/index.php/parc/article/view/8647437/15228. Accessed 17 Sept 2020

19. Hay R, Samuel F, Watson KJ, Bradbury S (2018) Post-occupancy evaluation in architecture: experiences and perspectives from UK practice. Build Res Inf 46(6):698-710 Available at: https:// www.tandfonline.com/doi/full/10.1080/09613218.2017.1314692. Accessed 17 Sept 2020

20. Assoni AD, Ornstein SW (2019) Museus interativos sob a ótica dos usuários. Avaliação Pós-Ocupação aplicada no caso do Museu Catavento, SP. Cadernos do PROARQ, 33, 111-132. Available in: http://cadernos.proarq.fau.ufrj.br/public/docs/Proarq33\%20art\% 206\%20111-132.pdf. Access in 05 Sept 2020

21. Souza RMD, Ornstein SW (2020) Gestão de museus a partir da aplicação da Avaliação Pós-Ocupação. O caso do Museu Histórico e Cultural de Jundiaí, São Paulo. Anais do Museu Paulista: História e Cultura Material, 28. Available at: https://www.revis tas.usp.br/anaismp/article/view/159856. Accessed 13 Sept 2020

22. Lopes S, Ornstein SW (2018) O Potencial da Avaliação PósOcupação (APO) para a preservação de ambientes museológicos localizados em edifícios antigos: O caso do Museu da Imigração, SP. Revista Projetar - Projeto e Percepção do Ambiente 3(2):67-79. Available at: https://periodicos.ufrn.br/revprojetar/ article/view/16547. Accessed 16 Sept 2020

23. Abate TP (2011) Instrumentos de Avaliação Pós-Ocupação (APO) adaptados a pré-escolares com deficiência física, auditiva e visual (Doctoral dissertation, Universidade de São Paulo). Available at: https://teses.usp.br/teses/disponiveis/16/16132/ tde-27012012-094114/pt-br.php. Accessed 24 Sept 2020

24. Mustafa FA (2017) Performance assessment of buildings via post-occupancy evaluation: A case study of the building of the architecture and software engineering departments in Salahaddin University-Erbil, Iraq. Front Archit Res 6(3):412-429 Available at: https://www.sciencedirect.com/science/article/pii/ S2095263517300407. Accessed 27 Sept 2020

25. Yu X, Liu L, Wu X, Wu X, Wang Z, Liu Q, Shi G (2017) On a post-occupancy evaluation study of effects of occupant behavior on indoor environment quality in college buildings in Chongqing. Procedia Eng 205:623-627 Available at: https://www. sciencedirect.com/science/article/pii/S1877705817350877. Accessed 27 Sept 2020

26. Balbi RS, da Silva JCP (2010) Ergonomia e análise pós-ocupação: A relação entre ambiente, usuário e atividade. Uma contribuição da Ergonomia aos estudos da Arquitetura. Design Ergonômico-Estudos e Aplicações 17033: 2. Available at: https://www.researchgate.net/publication/282672979_Design_ Ergonomico_-_Estudos_e_Aplicacoes. Accessed 27 Sept 2020

27. Sarmento TS, Villarouco V, Gomes AS (2020) Arranjos espaciais e especificações técnicas para ambientes de aprendizagem adequados a práticas educacionais com blended learning. Ambiente Construído 20(1): 365-390. Available at: https://www.scielo.br/scielo.php?script $=$ sci_arttext\&pid $=$ S1678-8621202000 $0100365 \& \operatorname{lng}=$ en $\& n r m=$ iso \&tlng=pt. Accessed 10 Oct 2020

28. Attaianese E, Duca G (2012) Human factors and ergonomic principles in building design for life and work activities: an applied methodology. Theor Issues Ergon Sci 13(2):187-202 Available at: https://www.researchgate.net/publication/23320 0702_Human_factors_and_ergonomic_principles_in_build ing_design_for_life_and_work_activities_An_applied_metho dology/citations. Accessed 16 Sept 2020

29. Vasconcelos CSF, Villarouco V, Soares MM (2009) Avaliação Ergonômica do Ambiente Construído: Estudo de caso em uma biblioteca universitária. Revista Ação Ergonômica 4(1). Available at: https://www.revistaacaoergonomica.org/revista/index. php/ojs/article/view/87. Accessed 17 Sept 2020

30. Araújo G, Santos T, Banks R, Barros B (2020). Novos campi universitários de instituições públicas: análise de uma biblioteca à luz da Ergonomia do Ambiente Construído, p. 565-579. In: Anais do VIII Encontro Nacional de Ergonomia do Ambiente Construído e do IX Seminário Brasileiro de Acessibilidade Integral. São Paulo: Blücher, 2020. Available at: http://pdf.blucher. com.br.s3-sa-east-1.amazonaws.com/designproceedings/eneac 2020/50.pdf. Accessed 09 Nov 2020

31. Villarouco V; Silva TP, Medeiros M. RLM, de Oliveira AMA, Câmara HL (2020) Bibliotecas de faculdades de arquitetura sob o foco da ergonomia". Anais do VIII Encontro Nacional de Ergonomia do Ambiente Construído e do IX Seminário Brasileiro de Acessibilidade Integral 590-605. São Paulo: Blucher. Available at : http://pdf.blucher.com.br.s3-sa-east-1.amazonaws.com/desig nproceedings/eneac2020/47.pdf. Accessed 09 Nov 2020

32. Felix Neto AS, Valença MLRM, Medeiros MHR de, Costa TS (2020) Avaliação ergonômica de uma área de convivência em ambiente universitário - Mezanino do Centro de Artes e Comunicação da UFPE. Anais do VIII Encontro Nacional de Ergonomia do Ambiente Construído e do IX Seminário Brasileiro de Acessibilidade Integral, 1173-1187. São Paulo: Blucher. Available at: http://pdf.blucher.com.br.s3-sa-east1.amazonaws.com/designproceedings/eneac2020/95.pdf. Accessed Nov 92020

33. Heylighen A, Van der Linden V, Van Steenwinkel I (2017) Ten questions concerning inclusive design of the built environment. Build Environ 114:507-517 Available at: https://www.sciencedir ect.com/science/article/pii/S0360132316305005. Accessed 16 Sept 2020

34. Steinfeld E, Maisel J (2012) Universal design: creating inclusive environments. John Wiley \& Sons. Available at: https://books. google.com.br/books?hl=pt-BR\&lr=\&id=II6VV5iAW9cC\&oi= 
fnd $\&$ pg $=$ PR11\&ots $=$ Z31TYtqzVq \&sig $=$ HMoVI4vHpHrpeRJ iZIhm2v6RunI\&redir_esc $=\mathrm{y} \# \mathrm{v}=$ onepage $\& \mathrm{q} \& \mathrm{f}=$ false. Accessed 16 Sept 2020

35. Cohen, R., Duarte C, Brasileiro A (2012) Acessibilidade a Museus. Brasília: Ministério da Cultura. Cadernos Museológicos - Instituto Brasileiro de Museus. Available at: http://www. museus.gov.br/wp-content/uploads/2013/07/acessibilidade_a_ museu_miolo.pdf. Accessed 15 Sept 2020

36. Sarraf VP (2008) Reabilitação do museu: políticas de inclusão cultural por meio da acessibilidade (Doctoral dissertation, Escola de Comunicações e Artes da Universidade de São Paulo). Available at: http://www.museusacessiveis.com.br/arquivosDown/ 20190204151118_reabilitac§c£o_do_museu_âae_polc\%C2\% ADticas_de_inclusc£o_cultural_por_meio_da_acessibilidade_ âae_dissertac§c£o_de_mestrado_de_viviane_panelli_sarraf.pdf. Accessed 27 Sept 2020

37. de Raposo GO, Façanha IVT, Silva VS (2018) Acessibilidade para deficientes visuais em museus: um estudo de caso no Museu da Fotografia de Fortaleza. VII Encontro Nacional de Ergonomia do Ambiente Construído / VIII Seminário Brasileiro de Acessibilidade Integral, 1297-1307. São Paulo: Blucher. Available at: https://www.proceedings.blucher.com.br/articledetails/acessibilidade-para-deficintes-visuais-em-museusumestudo-de-caso-no-museu-da-fotografia-de-fortaleza-27981. Accessed 4 Oct 2020

38. Vergara LGL, Troncoso MU, Rodrigues GV (2018) Acessibilidade entre mundos: uma arquitetura mais inclusiva aos autistas. VII Encontro Nacional de Ergonomia do Ambiente Construído / VIII Seminário Brasileiro de Acessibilidade Integral, 536-546. São Paulo: Blucher. Available at: https://www.proceedings.blucher. com.br/article-details/acessibilidade-entre-mundos-uma-arqui tetura-mais-inclusiva-aos-autistas-27916. Accessed $27 \mathrm{Sept}$ 2020

39. Antonini B, Fransolin LC, Rodrigues JC, Bernardi N, Kowaltowski DCCK (2016) O jogo da arquitetura: Discutindo a acessibilidade para surdos. In: Anais do VI Encontro Nacional de Ergonomia do Ambiente Construído \& VII Seminário Brasileiro de Acessibilidade Integral. Blucher Design Proceedings, p. 517-528 v.2 n.7. São Paulo: Blücher, 2016. Available at: https:// www.proceedings.blucher.com.br/article-details/o-jogo-da-arqui tetura-discutindo-a-acessibilidade-para-surdos-22647. Accessed 24 Sept 2020

40. Baptista MB, Bernardi N (2016) A NBR 9050 e o uso do desenho universal na produção de arquitetura de espaços expositivos na cidade de São Paulo no período de 2004 a 2014: análise de projetos de Paulo Mendes da Rocha. Anais do VI Encontro Nacional de Ergonomia do Ambiente Construído \& VII Seminário Brasileiro de Acessibilidade Integral. Blücher Design Proceedings 2(7): 733-735. São Paulo: Blucher, 2016. Available at: https://www. proceedings.blucher.com.br/article-details/a-nbr-9050-e-o-usodo-desenho-universal-na-produo-de-arquitetura-de-espaos-expos itivos-na-cidade-de-so-paulo-no-periodo-de-2004-a-2014-anlisede-projetos-de-paulo-mendes-da-rocha-22668. Accessed $27 \mathrm{Sept}$ 2020

41. Pavlogeorgatos G (2003) Environmental parameters in museums. Build Environ 38(12):1457-1462 Available at: https://www.scien cedirect.com/science/article/pii/S0360132303001136. Accessed 16 Sept 2020

42. da Silva Livramento RF, Costa ADL (2018) Percepção sensorial, design universal e usabilidade sob a ótica da prática projetual centrada no usuário. VII Encontro Nacional de Ergonomia do Ambiente Construído / VIII Seminário Brasileiro de Acessibilidade Integral 4(2):406-417. São Paulo: Blücher. Available at: http://pdf.blucher.com.br.s3-sa-east-1.amazonaws.com/designproc eedings/eneac2018/030.pdf. Accessed 14 Sept 2020
43. Pereira AB Silva S, Paiva MAM, A. C. Maia, I. M. O. (2018). Identificação de barreiras físicas em ambientes construídos. VII Encontro Nacional de Ergonomia do Ambiente Construído / VIII Seminário Brasileiro de Acessibilidade Integral, 491-500. São Paulo: Blucher. Available at: https://www.proceedings.blucher. com.br/article-details/identificao-de-barreiras-fsicas-em-ambie ntes-construdos-27912. Accessed 27 Sept 2020

44. Almeida E, Mont'alvão C (2020) Acessibilidade em museus para pessoas com deficiência visual: a influência do ambiente construído na experiência de visita, p. 181-190. In: Anais do VIII Encontro Nacional de Ergonomia do Ambiente Construído e do IX Seminário Brasileiro de Acessibilidade Integral. São Paulo: Blücher, 2020. Available at: https://www.proceedings.blucher. com.br/article-details/acessibilidade-em-museus-para-pessoascom-deficincia-visual-a-influncia-do-ambiente-construdo-naexperiência-de-visita-34788. Accessed 9 Nov. 2020

45. Vasconcelos BM, Oliveira VS (2020) Diretrizes para projeto de ambiente construído inclusivo (pessoas com deficiência auditiva). Gestão \& Tecnologia De Projetos 15(2): 98-112. Available at: https://www.revistas.usp.br/gestaodeprojetos/article/view/162777. Accessed 24 Oct 2020

46. Elali GA, de Lima MA (2016) O banheiro acessível sob o olhar do usuário. p. 413-423. Anais do VI Encontro Nacional de Ergonomia do Ambiente Construído \& VII Seminário Brasileiro de Acessibilidade Integral. Blucher Design Proceedings, v.2 n.7. São Paulo: Blücher. Available at: https://www.proceedings.bluch er.com.br/article-details/o-banheiro-acessvel-sob-o-olhar-do-usurio-22638. Accessed 20 Sept 2020

47. Ono R, Moreira KB (2011) Segurança em museus. Brasília: IBRAM. Available at: https://www.museus.gov.br/wp-content/ uploads/2012/08/Seguranca-em-Museus.pdf. Accessed $10 \mathrm{Sept}$ 2020

48. Franco MIM (2018) Planejamento e Realizações de Exposições. Cadernos Museológicos - Instituto Brasileiro de Museus Vol 3. Available at: https://www.museus.gov.br/wp-content/uploads/ 2019/06/PlanejamentoRealizacaoExposicoes.pdf. Accessed 15 Sept 2020

49. Cossio G, Cattani A (2010) Design de exposição e experiência estética no museu contemporâneo. In Congresso de Arquitetura de Museus PROARQ, Rio de Janeiro. Available at: https://www. arquimuseus.arq.br/anais-seminario_2010/eixo_ii/p2-artigo_gusta vo_cossio_airton_cattani.pdf. Accessed 28 Sept 2020

50. Primo JS (2006) Museologia e design na construção de objectos comunicantes. Caleidoscópio: Revista de Comunicação e Cultura, n 7. Available at: http://revistas.ulusofona.pt/index.php/caleidosco pio/article/view/2290. Accessed 20 Sept 2020

51. Ennes EG (2008) Espaço construído: o museu e suas exposições. Rio de Janeiro (Master's thesis Universidade Federal do Estado do Rio de Janeiro/Museu de Astronomia e Ciências Afins) Available at: http://livros01.livrosgratis.com.br/cp102741.pdf. Accessed 2 Sept .2020

52. Wang N, Xia L (2019) Human-exhibition interaction (HEI) in designing exhibitions: A systematic literature review. Int J Hosp Manag 77:292-302 Available at: https://www.sciencedirect.com/ science/article/pii/S0278431917310368. Accessed 27 Sept 2020

53. Mustafa WS, Taha AH (2020) The effect of museums' internal spaces characteristics upon visitors' space use patterns: Qatar museums as a case study. In: IOP conference series: materials science and engineering (Vol. 870, no. 1, p. 012012). IOP Publishing. Available at: https://iopscience.iop.org/article/10.1088/ 1757-899X/870/1/012012/pdf. Accessed 27 Sept. 2020

54. Medeiros MM, de Medeiros WG (2018) O design para a experiência na exposição do Museu Cais do Sertão. Estudos em Des 26(1): 5. Available at: https://eed.emnuvens.com.br/ design/article/view/70. Accessed 23 Sept 2020 
55. Chelini MJE, Lopes SGBDC (2008) Exposições em museus de ciências: reflexões e critérios para análise. Anais do Museu Paulista: História e Cultura Material 16(2): 205-238. Available at: https://www.revistas.usp.br/anaismp/article/view/5497. Accessed 4 Oct 2020

56. ICOM-CC (2014). Environmental Guidelines. Available at: http://www.icom-cc.org/332/-icom-cc-documents/declarationon-environmental-guidelines/\#.X2jVNi3OphA . Accessed 10 Sept 2020

57. UNESCO (2015) Proposal for a non-binding standard-setting instrument on the protection and promotion of various aspects of the role of museums and collections. General Conference, 38th. Available at: https://unesdoc.unesco.org/ark:/48223/pf00002338 92. Accessed 21 Sept 2020

58. Machado TG (2015) Projeto expográfico interativo: da adoção do dispositivo à construção do campo da interatividade (Doctoral dissertation, Universidade de São Paulo) Available at: https://www. sucupiracapesgovbr/sucupira/public/consultas/coleta/trabalhoCo nclusao/viewTrabalhoConclusaojsf?popup $=$ true \&id_trabalho $=$ 2836804. Accessed 2 Sept 2020

59. Lupo BM (2019) O museu como espaço de interação: arquitetura, museografia e museologia. Revista CPC, São Paulo 14(27): 217 243. Available at: http://www.revistas.usp.br/cpc/issue/view/ 10997/1656. Accessed 9 Sept 2020

60. Ahmad S, Abbas MY, Yusof WZM, Taib MZM (2013) Museum learning: using research as best practice in creating future museum exhibition. Procedia Soc Behav Sci 105:370-382 Available at: https://www.sciencedirect.com/science/article/pii/S187704281 3044145. Accessed 27 Sept 2020

61. Ahmad S, Abbas MY, Taib MZM, Masri M (2014) Museum exhibition design: communication of meaning and the shaping of knowledge. Procedia Soc Behav Sci 153:254-265 Available at: https://www.sciencedirect.com/science/article/pii/S187704281 4055013. Accessed 27 Sept 2020

62. Rahimi FB, Levy RM, Boyd JE, Dadkhahfard S (2018) Human behaviour and cognition of spatial experience; a model for enhancing the quality of spatial experiences in the built environment. Int J Ind Ergon 68:245-255 Available at: https://www.scien cedirect.com/science/article/pii/S0169814118300295. Accessed 16 Sept 2020

63. CIDOC, ICOM (2014) Declaração dos princípios de documentação em museus e Diretrizes internacionais de informação sobre objetos: categorias de informação do CIDOC. São Paulo: Secretaria de Estado de Cultura de São Paulo. Available at: http:// cidoc.mini.icom.museum/wp-content/uploads/sites/6/2020/03/ CIDOC-Declaracao-de-principios.pdf. Accessed 20 Sept 2020

64. ICOM-CECA (2020) Best practices in museum education and cultural programmes. Planning, developing and evaluating a programme. Available at: http://ceca.mini.icom.museum/wp-conte nt/uploads/sites/5/2020/01/ENGLISH_2019_BP_tool_2016.pdf. Accessed 21 Sept 2020

65. ICOM (2017) Código de ética do ICOM para Museus. Available at: https://icom.museum/wp-content/uploads/2018/07/Portuguese. pdf. Accessed 21 Sept 2020

66. Associação Brasileira de Normas Técnicas - ABNT (2013) NBR 15575: Edificações habitacionais — desempenho - Parte 1: requisitos gerais. Rio de Janeiro

67. Associação Brasileira de Normas Técnicas - ABNT (2020) NBR ISO 41001: Facility management — sistemas de gestão — requisitos com orientações para uso. Rio de Janeiro

68. Associação Brasileira de Normas Técnicas - ABNT (2017) NBR 10152: Acústica — níveis de pressão sonora em ambientes internos a edificações. Rio de Janeiro

69. Associação Brasileira de Normas Técnicas - ABNT (2013) NBR 10898: Sistema de iluminação de emergência. Rio de Janeiro
70. Associação Brasileira de Normas Técnicas - ABNT (2020) NBR 9050: Acessibilidade a edificações, mobiliário, espaços e equipamentos urbanos. Rio de Janeiro

71. Associação Brasileira de Normas Técnicas - ABNT (2016) NBR 16452: Acessibilidade na comunicação - audiodescrição. Rio de Janeiro

72. Associação Brasileira de Normas Técnicas - ABNT (2016) NBR 16537: Acessibilidade - sinalização tátil no piso - diretrizes para elaboração de projetos e instalação. Rio de Janeiro

73. Companhia de Engenharia de Tráfego - CET (2016) Regulamentação de Estacionamento e Parada- Deficiente Físico. Manual de Sinalização Urbana, volume 10, part 5. Available at: http://www. cetsp.com.br/media/392055/msu-vol-10-parte-5-deficiente-fisicorev-05.pdf. Accessed 19 Oct 2020

74. Associação Brasileira de Normas Técnicas - ABNT (2016) NBR ISO 20282-1: Facilidade de operação de produtos de uso diário - Parte 1: requisitos de projeto para o contexto de uso e as características do usuário. Rio de Janeiro

75. Associação Brasileira de Normas Técnicas - ABNT (2011) NBR ISO 9241-11: Requisitos ergonômicos para o trabalho com dispositivos de interação visual - Parte 11: orientações sobre usabilidade. Rio de Janeiro

76. Ministério do Trabalho e Emprego - MTE (2018) NR 17 - Ergonomia. Brasília: Ministério do Trabalho e Emprego Available at: https://www.targetcombr/pdfjs/web/viewerhtml?file=/cache viewer/27/89132/\{CED93F9D-AF39-49BE-9BEA-71FD620D48 28\}/178793168/14/elisabethfu@ uspbr\#page=1\&zoom=pagewidth\&search=ERGONOMIA\%20ERGONOMIA. Accessed 10 Oct 2020

77. Corpo de Bombeiros do Estado de São Paulo- CBPMESP (2019) Instrução Técnica 02/19 - Conceitos Básicos de Segurança Contra Incêndio. São Paulo. Available at: https://bombeiros.com.br/instr ucoes-tecnicas/. Accessed 28 Sept. 2020

78. Corpo de Bombeiros do Estado de São Paulo - CBPMESP (2019) Instrução Técnica 11/19 - Saídas de emergência. São Paulo. Available at: https://bombeiros.com.br/instrucoes-tecnicas/. Accessed 28 Sept 2020

79. Corpo de Bombeiros do Estado de São Paulo - CBPMESP (2019) Instrução Técnica 20/19 - Sinalização de emergência. São Paulo. Available at: https://bombeiros.com.br/instrucoes-tecnicas/. Accessed 28 Sept 2020

80. Corpo de Bombeiros do Estado de São Paulo - CBPMESP (2019) Instrução Técnica 40/19 - Edificações históricas, museus e insti tuições culturais com acervos museológicos. São Paulo. Available at: https://bombeiros.com.br/instrucoes-tecnicas/. Accessed 28 Sept 2020

81. Corpo de Bombeiros do Estado de São Paulo - CBPMESP (2019) Instrução Técnica 43/19 - Adaptação às normas de segurança contra incêndio - edificações existentes. São Paulo. Available at: https://bombeiros.com.br/instrucoes-tecnicas/. Accessed 28 Sept 2020

82. São Paulo (SP) (2017) LEI N ${ }^{\circ} 16.642$, de 9 de mai. de 2017. Código de Obras e Edificações do Município de São Paulo. São Paulo. Available at: http://legislacao.prefeitura.sp.gov.br/leis/lei16642-de-09-de-maio-de-2017/. Accessed 8 Oct 2020

83. São Paulo (SP) (2016) LEI N ${ }^{\circ}$ 16.402, de 22 de mar. de 2016. Plano Diretor Estratégico do Município de São Paulo. São Paulo. Available at: http://legislacao.prefeitura.sp.gov.br/leis/ lei-16402-de-22-de-marco-de-2016\#anexos. Accessed 10 Oct 2020

84. Saft JB (2021) Qualidade ambiental na gestão de áreas de guarda de acervos em papel em edifícios históricos na cidade de São Paulo. (Doctoral dissertation, Universidade de São Paulo). Avalilable at.: https://www.teses.usp.br/teses/disponiveis/16/16132/tde08062021-202718/pt-br.php. Accessed 30 Sept 2021 
85. Instituto do Patrimônio Artístico e Nacional - IPHAN (1937) Decreto-lei No 25, de 30 de nov de 1937 Decreto-lei No 25 Rio de Janeiro Available at: http://www.portaliphangovbr/uploads/ legislacao/Decreto_Lei_n_25_de_30_de_novembro_de_1937 pdfpdf. Accessed 19 Oct 2020

86. de Neves RA, da Neves ASO (2018) A Importância da ergonomia do ambiente construído nos projetos arquitetônicos - o caso dos deficientes auditivos. VII Encontro Nacional de Ergonomia do Ambiente Construído / VIII Seminário Brasileiro de
Acessibilidade Integral, 547-644. São Paulo: Blucher. Available at: https://www.proceedings.blucher.com.br/article-details/aimportancia-da-ergonomia-do-ambiente-construdo-nos-projetosarquitetnicos-o-caso-dos-deficientes-auditivos-27917. Accessed 27 Sept. 2020

Publisher's note Springer Nature remains neutral with regard to jurisdictional claims in published maps and institutional affiliations. 